\section{Immundiffusion, zweidimensionale}

R. Westermeier

Freising, Deutschland

Synonym(e) Ouchterlony-Technik; Radiale Doppeldiffusion

Englischer Begriff Ouchterlony double diffusion in two dimensions

Definition Bei der zweidimensionalen Immundiffusion nach Ouchterlony werden Antigen- und Antikörperlösungen in kleine Löcher einpipettiert, die in eine leere Agarosegelschicht gestanzt wurden. An den Äquivalenzpunkten der kreisförmig gegeneinander diffundierenden Antigene und Antikörper bilden sich Präzipitatbögen.

Physikalisch-chemisches Prinzip Mit der OuchterlonyTechnik erhält man in kurzer Zeit mit wenig Aufwand Informationen über immunologische Identität von Antigenen. Bei dieser Technik enthält das Gel keine Antikörper. Sowohl Antigen als auch Antikörper diffundieren ringförmig aus dem jeweiligen gestanzten Loch und bilden Konzentrationsgradienten. Während beide ineinander diffundieren, bildet sich am Äquivalenzpunkt eine scharfe Präzipitatlinie. Man kann um das Antikörperloch herum mehrere Antigenlöcher stanzen und eine Anzahl verschiedener Proben aufgeben. Die Präzipitatbögen werden mit - Coomassie-Färbung detektiert. Aus dem Vorhandensein/ Nichtvorhandensein und der Form der Präzipitatbögen wird auf immunologische Identität der Probenantigene geschlossen (s. Abbildung).

Schematische Darstellung von möglichen Ergebnissen; Antigene können auf immunologische Identität überprüft werden ( $A g$, Antigen; $A k$, Antikörper):

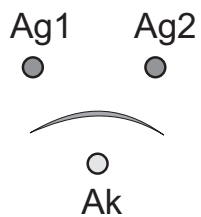

Antigene sind identisch

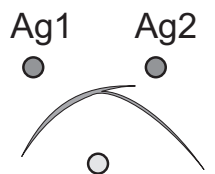

Ak

$$
\begin{aligned}
& \text { Antigene sind } \\
& \text { partiell identisch }
\end{aligned}
$$

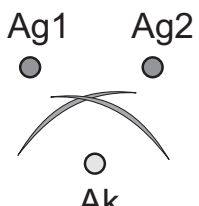

Ak

Antigene sind nicht identisch

Einsatzgebiet Test auf immunologische Identität von Antigenen.

Untersuchungsmaterial Serum.

Instrumentierung Man benötigt Glasplatten oder Petrischalen und eine Stanze, die an ein Vakuum oder eine Wasserstrahlpumpe angeschlossen ist.

Spezifität Diese Methode ist hochspezifisch.

Sensitivität Die Empfindlichkeit liegt im $\mu$ g-Bereich der Antigenkonzentrationen. Die Empfindlichkeit der Coomassie-gefärbten Immunpräzipitate liegt bei $18 \mathrm{ng} / \mathrm{mm}^{2}$.

Fehlermöglichkeit Ungleichmäßige Gelschicht.

Praktikabilität - Automatisierung - Kosten Die Methode ist einfach, leistungsfähig und in wenigen Stunden durchführbar. Kein automatisiertes Verfahren verfügbar. Die Materialkosten sind wegen der geringen Antikörpermenge im Gel vergleichsweise niedrig.

\title{
Literatur
}

Ouchterlony Ö (1949) Antigen-antibody reactions in gels. Acta Path 26:507

Lottspeich F, Engels JW (Hrsg) (2012) Bioanalytik, 3. Aufl. Spektrum Akademischer Verlag, Heidelberg 